\title{
A COMPARISON STUDY ON USERS' CHARACTERISTICS AND RECREATIONAL ACTIVITIES BETWEEN A PARK WITH RESERVOIR AND ANOTHER WITHOUT RESERVOIR
}

- Characteristics of recreational activities at reservoir's waterfront area-

\author{
ため池のある公園とない公園における利用者特性と余层活動の比較分析 \\ 一ため池の水辺空間における利用特性に関する研究—
}

\author{
Akira TOMORI*, Hirotaka SUZUKI** and Masuro URA YAMA*** \\ アキラトモリ，鈴木宏隆，浦山益郎
}

\begin{abstract}
Reservoirs are artificial lakes built as agricultural facilities, and play a significant role as urban resources. A comparison study through observation and questionnaire survey between a park with reservoir and another without reservoir was conducted to examine the characteristics of recreational activities at reservoir's waterfront area. In a park with reservoir, passive recreational, active recreational and walking were observed at waterfront area, which includes the walking path and the bank. Walking was the dominant recreational activity in this area and the majority of this recreational activity was daily or weekly - elderly users. Users that came to walk in a park with reservoir were more and stayed longer than in a park without reservoir due to opportunities for enjoying the aesthetical quality that the reservoir and the environment provide.
\end{abstract}

Keywords: Park, Reservoir, Water Front Area, Users Characteristics, Recreational Activities 公園、ため池、水辺空間、利用者特性、余暇活動

\section{Introduction}

Open spaces with green and water are essential in helping to build healthy urban environments by improving air quality and providing recreational opportunities for urban lifestyle. Therefore reservoirs are artificial lakes built as an agricultural facility for irrigation, what is more, they have possibility to play a significant role in urban areas. It has been shown that reservoirs have use effect, open space effect and symbol effect ${ }^{1}$. However, information to utilize reservoir as an urban resource is still limited.

Most of the previous studies on reservoirs have been focused on the water management related to irrigation, maintenance and conservation, and distribution of irrigation ponds ${ }^{2)}$ ). Some researchers have studied reservoir as an urban resource ${ }^{78)}$. And besides a research related to sitting behavior in a park with round pond ${ }^{9}$, little has been done for investigating the characteristics of reservoirs' water front area.

The objective of this paper is to clarify characteristics of recreational activities at reservoir's water front area, in order to find information needed to design reservoir as an urban resource in parks. Two sorts of survey were carried out to compare users' characteristics and recreational activities between a park with reservoir and another without reservoir, and to analyze the effects and benefits of reservoir on users activities.

\section{Methodology}

\section{1) Study area}

Two sorts of survey were carried out at two parks in Tenpaku ward, Nagoya city: Hosoguti-ike Park with reservoir and Ueda-chuo Park without reservoir. Figure 1 shows the land use and facilities in both parks. The surrounding context is similar: housing and junior high schools are adjacent to each park. The facilities in each park are also similar: both have play fields, playgrounds that have some play equipments, and walking paths. Furthermore, as shown in the section drawing, each park has bank*1) including walking paths. Though Hosoguti-ike Park is designated as a district park and Ueda-chuo Park is a neighborhood park, in each park daily and weekly users are the majority, which is described later. Differences are size and facilities; the reservoir and the tennis court in Hosoguti-ike Park and the small field in Ueda-chuo Park.

\section{2) Questionnaire and Field survey}

Field surveys and questionnaire surveys were carried out twice, on weekday and weekend from 6a.m. to 6p.m., during October in 2004 (Table $1,2)$. To see number, location and types of activities in each park, users were plotted every 20 minutes from 6a.m. to 5:40p.m. Dots a, b and $\mathrm{c}$ in figure 1 show the positions of the investigators (two in Hosoguti-ike Park and one in
* Graduate Student, Graduate School of Eng., Mie Univ., M. Eng.

** Graduate Student, Graduate School of Eng., Mie Univ.

*** Prof., Dept. of Architecture, Faculty of Eng., Mie Univ., Dr. Eng.
三重大学大学院工学研究科 大学院生・工修

重大学大学院工学部研究科 大学院生

三重大学工学部建築学科 教授. 工博 


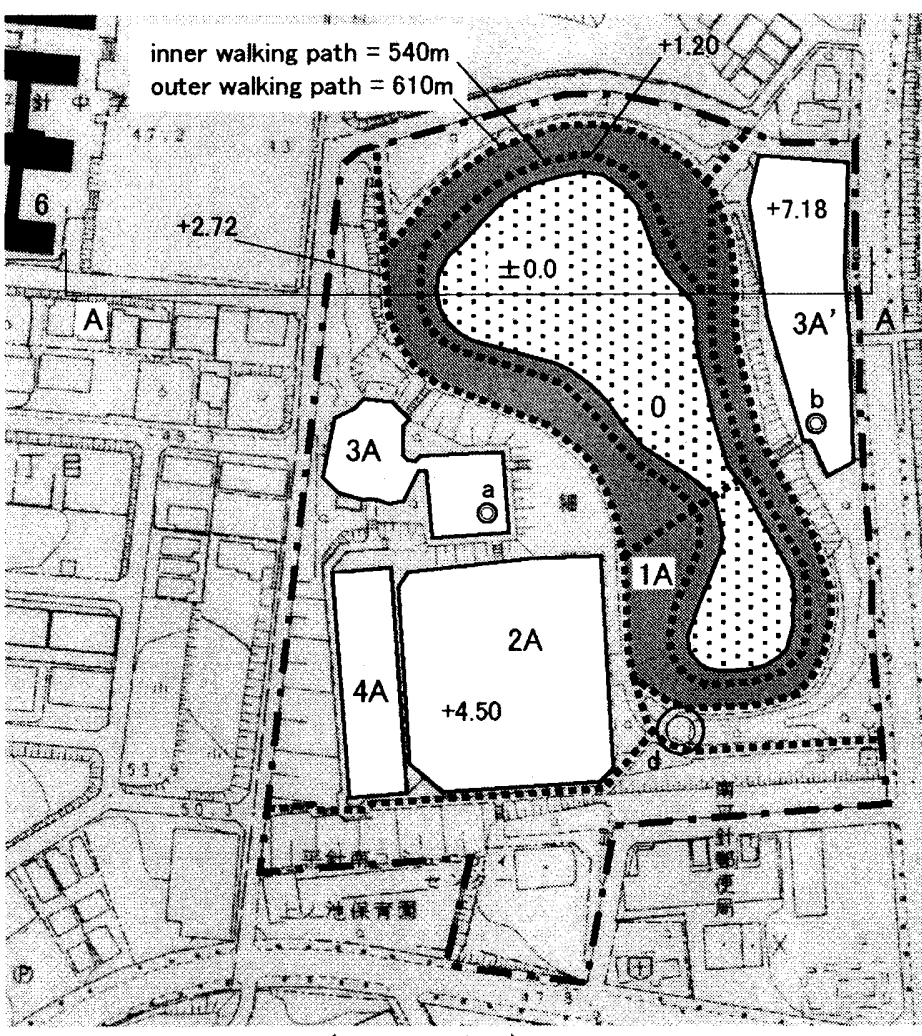

Hosoguti-ike Park Plan ( area $=4.22 \mathrm{ha})$

Section A-A'

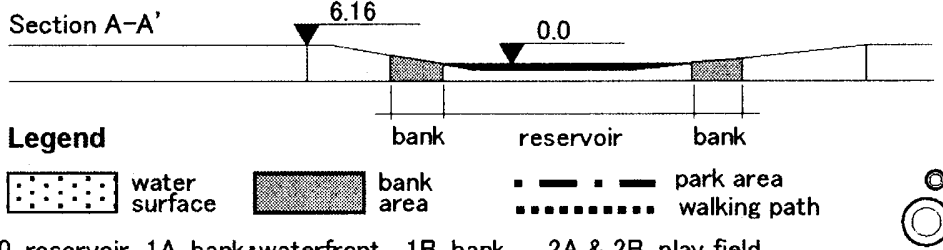

0 . reservoir 1A. bank "waterfront $1 B$. bank $2 A \& 2 B$. play field

$3 A, 3 A^{\prime} \& 3 B$. playground $4 A$. tennis court $5 B$. small field 6 . junnior high school

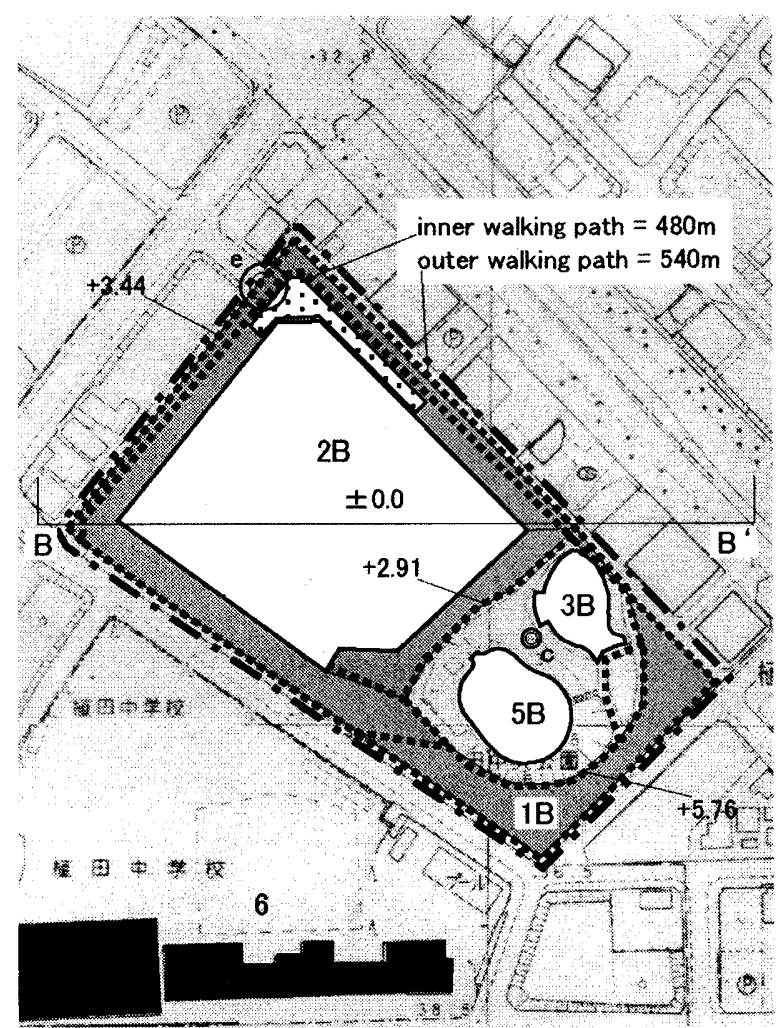

Ueda-chuo Park Plan ( area $=2.0 \mathrm{ha})$

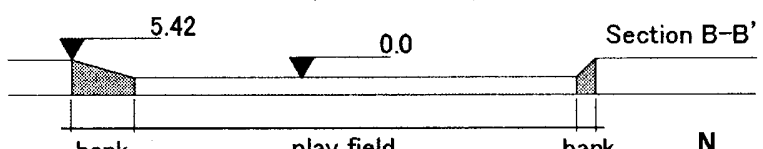

investigator's position (observation survey)

investigator's position (questionnaire survey)

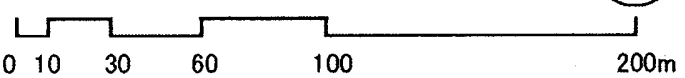

Figure 1. Plan, section and surrounding context of each park

Table 1. Date and weather of questionnaire and observation survey

\begin{tabular}{|c|c|c|c|}
\hline & date & weather & average temperature \\
\hline \multirow[t]{2}{*}{ Hosoguti-ike Park } & october 17 th & mostly sunny & 17.8 \\
\hline & october 18 th & mostly sunny & 18.7 \\
\hline \multirow[t]{2}{*}{ Ueda-chuo Park } & october 24th & mostly sunny & 15.9 \\
\hline & october 25 th & mostly sunny & 19.3 \\
\hline
\end{tabular}

Ueda-chuo park) in the observation survey. In Hosoguti-ike Park, investigator "a" was in charge of zones $2 \mathrm{~A}$ (play field), $3 \mathrm{~A}$ (play ground) and $4 \mathrm{~A}$ (tennis court). Investigator " $\mathrm{b}$ " was in charge of zones $1 \mathrm{~A}$ (walking path and bank area) and $3 \mathrm{~A}^{\prime}$ (playground). In Ueda-chuo Park, investigator " $\mathrm{C}$ " was in charge of zones $1 \mathrm{~B}, 2 \mathrm{~B} 3 \mathrm{~B}$ and $5 \mathrm{~B}$. In all cases, they were in a place with good visibility of the designated area ${ }^{*^{2}}$. Types of activities were divided in walking, passive recreational and active recreational as is described in chapter 3. Each type was plotted in a map (plan of the park with all details) prepared before. In the questionnaire survey, one investigator was positioned close to the entrance on the edge of each park (dots $d$ and e). Adults and kids above 10years old were interviewed; 147 users in Hosoguti-ike Park and 119users in Ueda-chuo Park. In case of groups (baseball teams, ground golf teams) the questionnaire was conducted to tree or four users, and in case of families, to one adult.
Table2. Items of the questionnaire

\begin{tabular}{lll}
\hline \multicolumn{1}{c}{ users' } & way to access & way to use and reason \\
\hline 1. Gender & 3. Way of journey & 6. Frequency \\
2. Age & 4. Time of journey & 7. Time spent \\
& 5. Number of people & 8. Variety of activities \\
& & 9. Reason to use the park \\
\hline
\end{tabular}

\section{Recreational activities of each park}

1) Types and number of activities

Figure 2 to Figure 5 show type and number of activity in each park. Users who were jogging, playing sports, playing with friends ${ }^{* 3)}$, playing with kids and catching insects, can be classified as active recreational. Users who were resting, eating or picnicking, reading, chatting, dating, taking a nap and activities related to watching the scenery (green, flowers, lake, birds, animals and insects) can be classified as passive recreational. And users who were walking can be classified different from these groups. The total number of activities in Hosoguti-ike Park on a weekend day is 4463 , and in Ueda-chuo Park is 3040 . The total number of activities on a weekday in Hosoguti-ike Park is 1607 , and in Ueda-chuo Park is 1768. Each park has more visitors on a weekend day. The average of activities per 20 minutes in Hosoguti-ike Park is 84.3 and in Ueda-chuo Park, 66.8 ${ }^{* 4)}$. 
Figure 2 shows the number of activities in Hosoguti-ike Park on a weekend day, and Figure 3 shows it on a weekday. The number of passive recreational and the number of walking is similar between weekday and weekend. The difference of them is the number of active recreational. On Sunday, a sport event from 10a.m. to $2 . \mathrm{pm}$. is the reason for the large number of those activities. Figure 4 and Figure 5 are number of activities in Ueda-chuo Park. On Sunday, a local softball championship is the reason for the big number of active recreational. And passive recreational are also high due to users who were watching the game or players who were resting or eating. On Monday, active recreational increase due to the junior high school students who come to practice baseball in the afternoon.

Figure 2 to Figure 5 also indicate that number of walking is higher in a park with reservoir. In chapter 5 , it will be analyzed the reason of high number of walking in a park with reservoir.

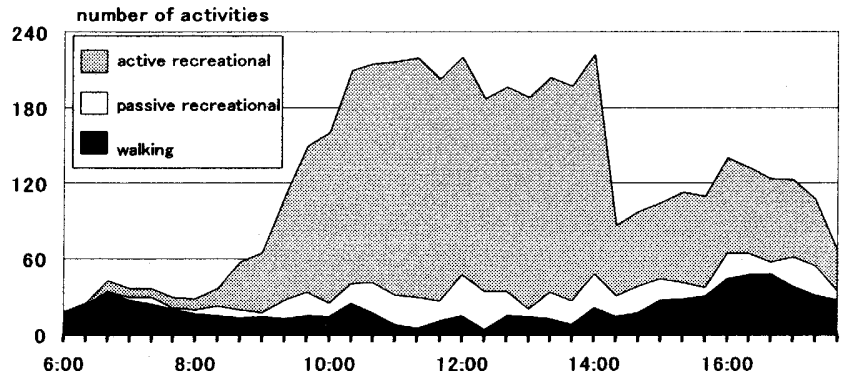

Figure 2. Number of activities in Hosoguti-ike Park (weekend-Sunday)

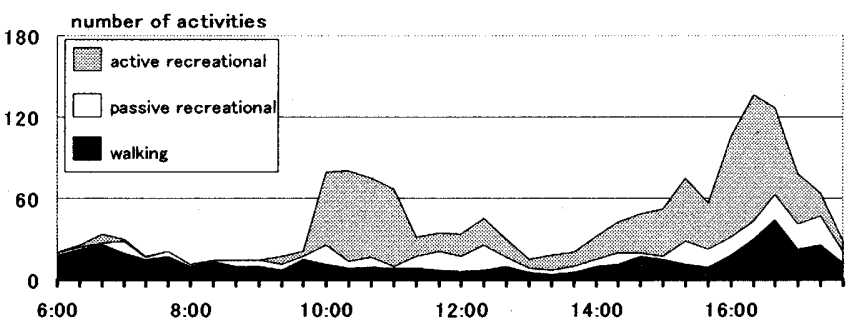

Figure 3. Number of activities in Hosoguti-ike Park (weekday-Monday)

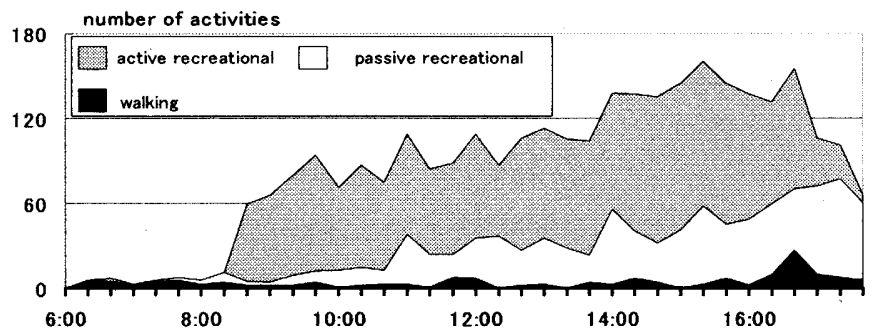

Figure 4. Number of activities in Ueda-chuo Park (weekend-Sunday)

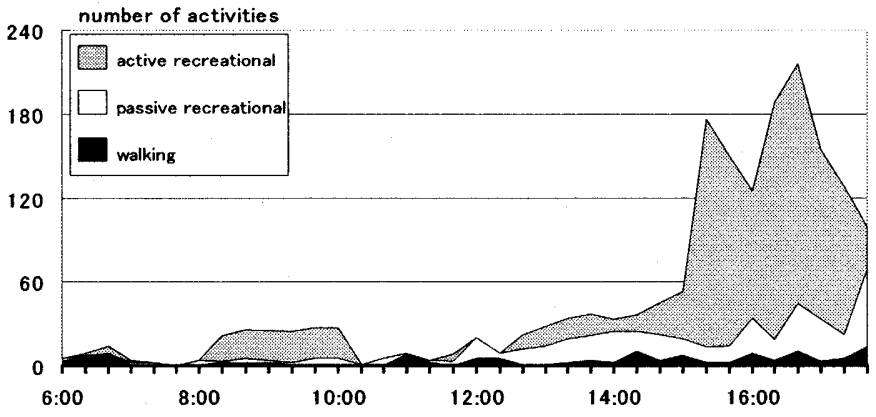

Figure 5. Number of activities in Ueda-chuo Park (weekday-Monday)

\section{2) Relation between type of activity and each zone}

Figure 6 shows types of activities and the relation to each zone. Type of recreational activity can be seen similarly in the play field (zones $2 \mathrm{~A}$ and $2 \mathrm{~B}$ ) and playground (zones 3A, 3A' and 3B) of each park Numbers of activities show that active recreational was dominant at the play field in each park. Groups of kids and adults played baseball or softball, groups of elderly played ground golf and small groups of kids played soccer and catch ball. And at the playground, parents with kids came to use the equipments such as seesaw and slide. The number of passive recreational is higher at the playground than in the play field due to parents that were using the benches for resting and chatting while were watching the kids.

Differences of users' distribution and type of activity can be seen on the gray zones (zone 1A and 1B), which include the bank and the walking path. The number of walking at zone $1 \mathrm{~A}$, which coincides with the waterfront area in Hosoguti-ike Park is 1122, and 303 at zone 1B in Ueda-chuo Park. The number in the former is higher due to more users who stay longer on the walking path than in the latter. As found in the questionnaire, most of them were elderly who use early in the moming and/or before the sun set.

Another difference is the distribution and nature of passive and active recreational at the bank. In Hosoguti-ike Park, passive recreational were observed at the waterfront. Waterfront areas including walking path and bank are not only places suitable for exercising such as walking and jogging, but also places to enjoy passive recreational. While, at the play field and playground in each park, passive recreational are concentrated on places where users could sit and rest such as benches, kiosks and stairs. At zone 1B, the number of passive recreational is high due to softball players that were eating and drinking on the stairs after the match. In addition, it was observed that the nature of active recreational is also different at the bank area. In Hosoguti-ike Park kids catch insects at the bank while in Ueda-chuo Park, kids use the bank for sliding.

\section{Users' profile of each park based on the questionnaire survey}

To see classification of recreational activities, interviewees from the questionnaire survey were analyzed.

\section{1) Number of people (way to access)}

Figure 7 to Figure 13 are the results of the questionnaire survey. Even though the questionnaire wasn't conducted to all users in both parks, figure 7 shows similarities; in each park, more than half of answers come alone, and almost $20 \%$ come with a company and the rest are families or groups.

\section{2) Gender and age}

Figure 8 indicates users' gender and Figure 9 indicates users' age in each park. Similar percentages of users' gender were found, however, there was a difference in users' age. Figure 9 shows that in Hosoguti-ike Park $40 \%$ of

\begin{tabular}{|c|c|c|}
\hline $57 \%$ & 208 & \% $12 \%$ \\
\hline \multicolumn{3}{|l|}{ Ueda-chuo Park } \\
\hline $54 \%$ & 238 & $28 \%$ \\
\hline
\end{tabular}

Figure 7. Number of people (way to access) 

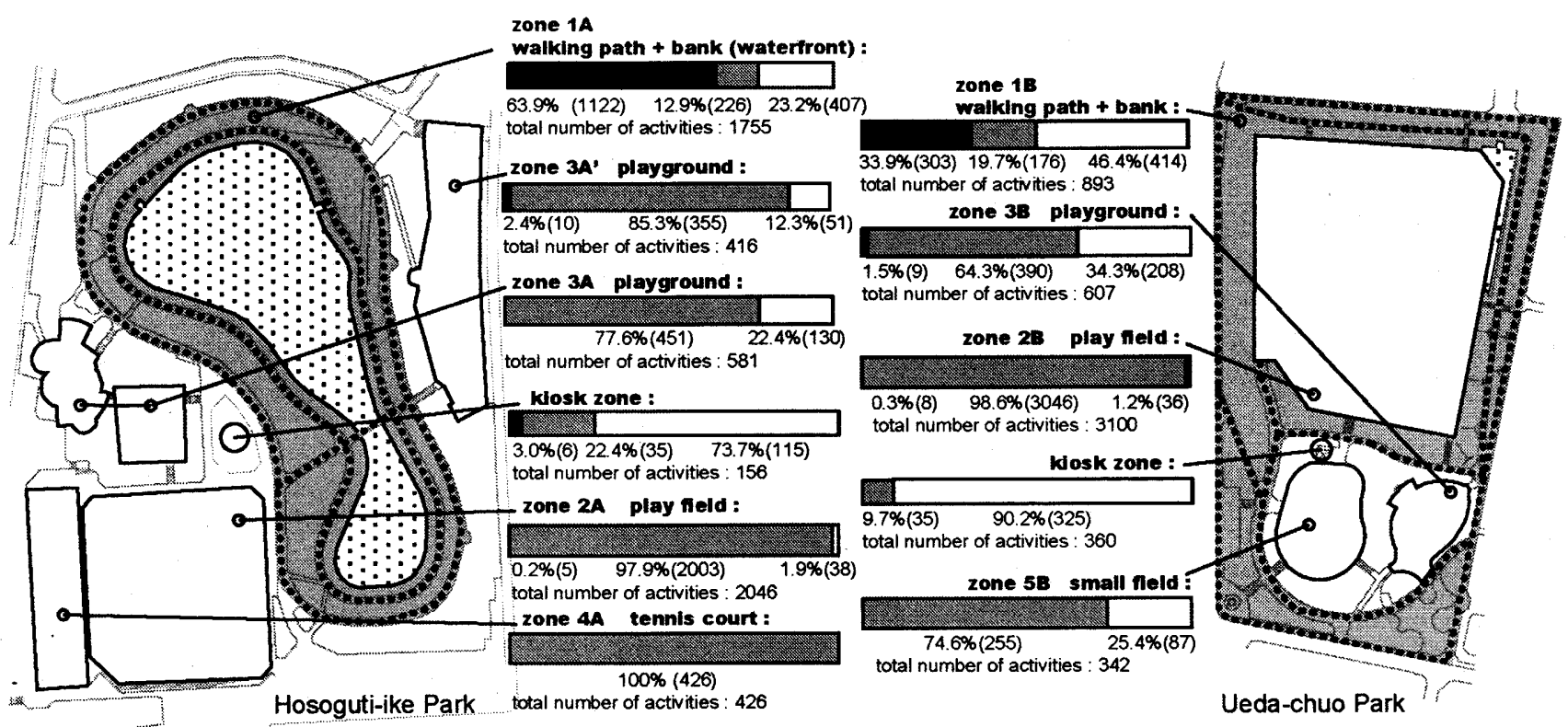

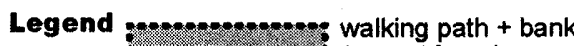
(zone 1A and zone 1B)

walking

active recreational

Opassive recreational

other facilities (zones $2 A / 2 B$, zones $3 A$ / 3B / 3C zone $4 A$ and zone $5 B$ )

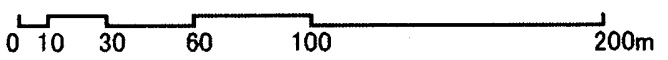

Figure 6. Relation between type of activities and each zone in both parks

(Results of observation survey from 6a.m. to 5:40p.m. - weekend day and weekday)

Hosoguti-ike Park $56 \%$ 448

Ueda-chuo Park
\begin{tabular}{|l|l|l|}
\hline & & \\
\hline male & $36 x$ & female
\end{tabular}

Figure 8. Gender

Hosoguti-ike Park

\begin{tabular}{|lll}
\hline $10 \% 4 \%$ & $40 \%$
\end{tabular}

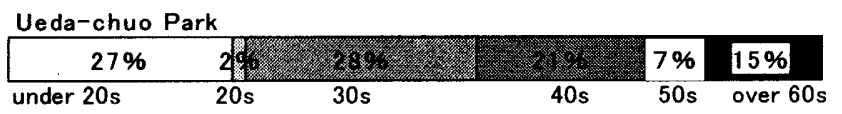

Figure 9. Users' age

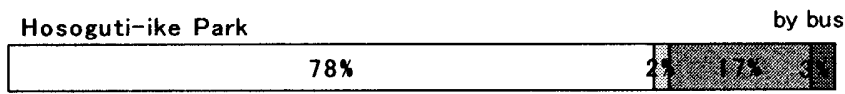

Ueda-chuo Park
\begin{tabular}{|c|c|c|}
\hline $53 \%$ & 228 & 28 \\
\hline on foot & by bicycle & by car
\end{tabular}

Figure 10. Way of journey

Hosoguti-ike Park

\begin{tabular}{|c|c|}
\hline $78 x$ & 176 \\
\hline \multicolumn{2}{|l|}{ Ueda-chuo Park } \\
\hline $78 \%$ & $20 x$ \\
\hline
\end{tabular}

Figure 11. Time of journey

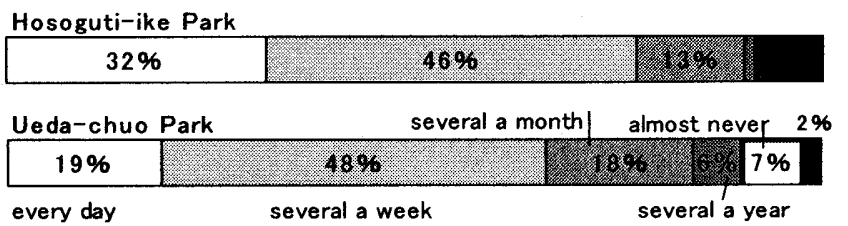

Figure 12. Frequency

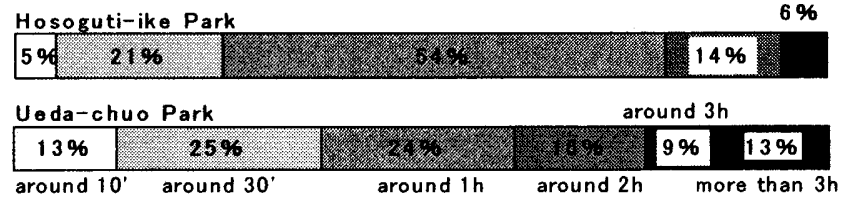

Figure 13. Time spent

the users were over $60 \mathrm{~s}$; and $27 \%$ of users in Ueda-chuo Park are under 20 years.

\section{3) Accessibility}

Residents who live close to parks are the majority of users (Figure 10 and Figure 11). Almost $80 \%$ of the users in Hosoguti-ike Park come on foot and time necessary for access is less than 10 minutes. And in Ueda-chuo Park, $75 \%$ of the users in neighborhood access on foot and by bicycle.

\section{4) Frequency and time spent}

Figure 12 indicates frequency and Figure 13 indicates time spent. Figure 12 shows that users who come every day and sometimes a week were the majority in each park. Daily users in Hosoguti-ike Park surpassed Ueda-chuo Park by thirteen percent. And Figure 13 shows that, 54\% of users in Hosoguti-ike Park stay for around one hour, more than twice the percentage in Ueda-chuo Park. As observed in the field survey, almost of them probably were elderly that walk around the reservoir.

\section{Classification of Users' Recreational Activities and their Characteristics}

1) Variety of recreational activities

To see the variety of recreational activities in each park, a questionnaire was conducted to choose multiply 26 items (Figure 14). Walking, jogging, playing sports, catching insects, playing with kids, playing with friends and camping, are prepared for active recreational. Watching the green, flower 

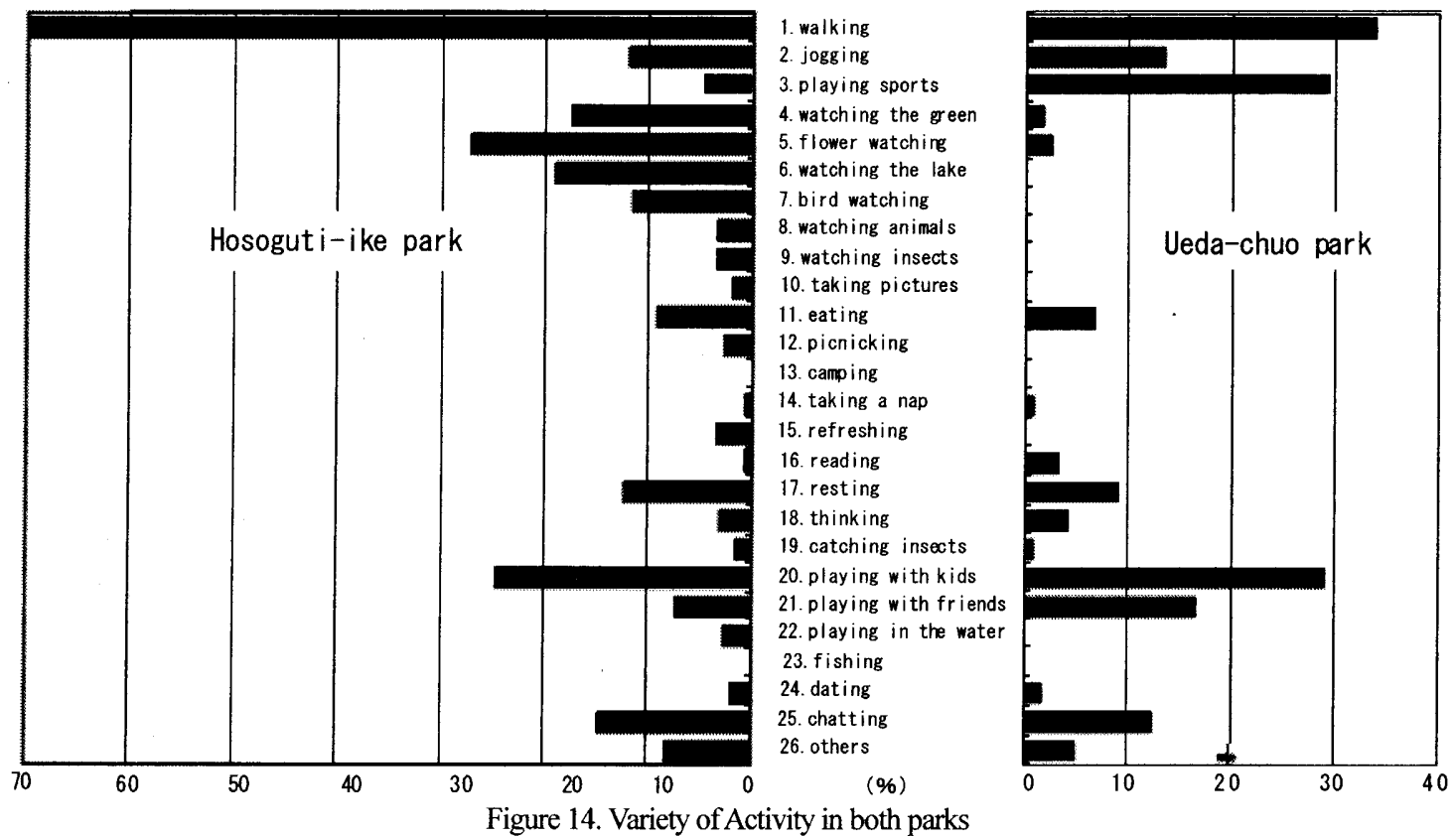

watching, bird watching, watching the animals, watching insects, taking pictures, eating, picnicking, taking nap, refreshing, reading, resting, thinking, dating and chatting are prepared for passive recreational. Watching the lake, playing in the water and fishing are recreational activities related directly to the water surface.

Each park has walking paths with similar length. However in Hosoguti-ike Park the percentage of users that came for walking is $70 \%$ and in Ueda-chuo Park is 34\% (Figure14). Another significant differences are activities related to enjoy the scenery. The percentage of watching the green, flower watching, watching the lake and bird watching were higher in the park with reservoir compared to the park without reservoir. To take photos is an activity also related to enjoy the scenery of reservoir that was observed only in Hosoguti-ike Park. The percentage of playing sports and playing with friends were higher in Ueda-chuo Park than in Hosoguti-ike Park, due to a big play field suitable for those kinds of activities.

\section{2) Classification of recreational activities}

In the questionnaire related to 'variety of activity', many users chose more than one activity. In order to classify different choices of recreational activities, the whole data set from both parks was adapted to k-means clustering analysis. Camping with no answer was excluded; watching animals and watching insects were jointed to bird watching; and picnicking was jointed to eating. Table 3 shows that recreational activities were classified in 7 patterns. Pattern 1 is [walking] and pattem 2 is [playing sports]. These are single purpose activities. Pattern 3 is [walking +flower watching], pattern 4 is [walking +watching the green +watching the lake], pattern 5 is [walking + watching the green +flower watching +watching the lake and bird watching] and pattern 6 is [walking +chatting]. Patterns 3,4,5 and 6 would say multiple purpose activities, which include walking and passive recreational. Pattem 7, which doesn't have a dominant recreational activity, can be classified as [others].

Percentage of users who come mainly for walking (pattem 1) is higher in Hosoguti-ike Park (59\%) than in Ueda-chuo Park (41\%) and patterns 3, 4 and 5 are strongly in favor of Hosoguti-ike Park. Many users in the park with reservoir come for walking and also to watch the green, flowers, the lake and birds. On the other hand, patterns related to playing spots, play with kids and friends (patterns 2 and 7) are statically significant in favor of Ueda-chuo Park.

In the park without reservoir, active recreational related to sports was the dominant activity, and in the park with reservoir, multiple purpose activities including walking and passive recreational related to watch the scenery were highly observed. Facilities and the attractiveness of each park reflect the selection of recreational activities.

\section{3) Characteristics of each pattern}

Table 4 shows cross tabulation between users' characteristics and each pattern. Similar percentages of users' frequency, way to access (transportation, distance from home and number of people) and gender were found in pattern 1 in both parks, however, there were differences in users' age and time spent. In Ueda-chuo Park, more than $60 \%$ of the users are 30 s and 40 s, while in Hosoguti-ike Park, $70 \%$ of users that came for walking are over 50 years. The majority of users' from Ueda-chuo Park stay from 10 to 30 minutes, while more than $80 \%$ of users in Hosoguti-ike Park, use from 30 minutes to one hour. Pattern 2 involves sport activities in groups (clubs) or among friends (small groups). More than $85 \%$ of users were at Ueda -chuo Park, who played baseball (under 20), soccer (under 20) and ground golf (over 60) for more than 3 hours. They are weekly and monthly users.

Patterns 3,4 and 5 contain walking and passive recreational such as flower watching, watching the green, watching the lake and bird watching. More than $50 \%$ of the users from patterns 3 and 5 in Hosoguti-ike Park are over 60 years, who come to walk and enjoy visual and aesthetical quality of the park. They are daily or weekly users and most of them come alone. Such passive activities may be linked with the benefits of the restorative opportunities that a park with reservoir provides, because these patterns cannot be seen in Ueda-chuo Park.

Pattern 6 includes walking and chatting. Almost $60 \%$ of users, who 
come to socialize and walk, in Hosoguti-ike Park are over 60 years, while in Ueda-chuo Park almost $70 \%$ are under 20 years. As observed in the field survey, many elderly were chatting at the waterfront. They were daily or weekly users and $64 \%$ of them use the park for around one hour. Users in pattern 7 are parents with kids that come on foot by bicycle or by car. Scores in table 4 show that users' characteristics from this pattern in both parks are similar.

\section{4) Reason to use of each pattem}

Beautiful landscape, richness of green, water surface, fauna and flora, to play at the waterfront, possible to catch insects, people are using, children can play, to exercise, for health, to refresh, to feel calm, close to home, wide, equipped park and others were the items prepared for a multiple-choice answer to examine the reason to use each park. Table 4 shows the cross tabulation between 'reason to use' and each pattern.

Looking the 'reason to use' of each pattern, for users of patterns 3,4, and 5 which include walking and passive recreational, richness of green and fauna and flora were highly evaluated. All these patterns link strongly to enjoy the scenery of reservoir and waterfront area. Users of patterns 2, [playing sports] links to exercise. Users of pattem1, 3, 4,5 and 6 in Hosoguti-ike Park, have a concem for health and visual landscape. And pattem 7, which includes eating \& picnicking + play with kids, link to opportunities for children.

For users in Hosoguti-ike Park, [beautiful landscape], [richness of green], [water surface] and [fauna and flora] are noteworthy reasons to use the park. The water surface and the surrounding environment have an important effect for users evaluation compared to a park without reservoir. On the other hand, for users in Ueda-chuo Park, the width and the condition of the play field are reasons to use this park.

Table 4 also indicates that [close to home] was highly scored in each park.
This is a reason why each park is used similarly as a residential resource.

\section{Conclusion}

This paper is focused on characteristics of recreational activities at reservoir's water front area to clarify the influence of reservoir on users activities. Based on observation survey and questionnaire between a park with reservoir and another without reservoir, conclusions are summarized as follows:

1) Facilities such as play field and playground have active recreational designated for these kind of design.

2) Walking is the dominant recreational activity at the reservoir's waterfront area. The majority of this recreational activity is daily or weekly elderly users. In addition, passive recreational such as, eating, picnicking and watching the scenery, and active recreational like catching insects can be also observed at the water front area.

3) Recreational activities can be classified in 7 patterns: 1 pattern is single purpose activity and 6 patterns are multiple purpose activities.

4) Pattern 1 (walking), pattern 6 (walking +chatting) and pattern 7 (others) are common patterns in both parks. Patterns 3,4 and 5 which are walking + watching the scenery are specific from Hosoguti-ike Park.

5) For users from patterns 3,4 and 5 , richness of green, fauna and flora and the water surface are reasons to use the park. These are related to aesthetical quality that the reservoir and the surroundings provide.

6) The potential design of reservoir in parks within urban areas should bring out the characteristics of reservoir's water front area permitting the expansion of those types of recreational activities and the enjoyment of the benefits of reservoir.

Table 3. Cross tabulation between recreational activities and each pattern (multiple answer)

\begin{tabular}{l}
\multicolumn{9}{c}{ Table 3. Cross tabulation between recreational activities and each pattern } \\
\hline
\end{tabular}


Table 4. Cross tabulation between users' characteristics / reason to use and patterns in each park

\begin{tabular}{|c|c|c|c|c|c|c|c|c|c|c|c|c|c|c|c|}
\hline \multicolumn{8}{|c|}{ Hosoguti-ike Park } & \multirow{2}{*}{\multicolumn{2}{|c|}{ users' characteristics }} & \multicolumn{6}{|c|}{ Ueda-chuo Park } \\
\hline the whole & pat 1 & pat 2 & pat 3 & pat 4 & pat 5 & pat 6 & pat 7 & & & pat 1 & pat 2 & pat 3 & pat 6 & pat 7 & the whole \\
\hline 53.5 & 42.0 & 100.0 & 53.3 & 66.7? & $66 \%$ & 42.9 & 588 & 1.gender & male & 52.8 & 828 & 50.0 & 25.0 & 675 & 62.2 \\
\hline 46.5 & 580 & & 46.7 & 33.3 & 33.3 & 571: & 41.2 & & female & 472 & 17.2 & 500 & 750 & 32.5 & 37.8 \\
\hline 4.1 & & & & 5.6 & & 7.1 & 11.8 & 2.age & under 20 & 2.8 & 30.0 & & 66.7 & 225 & 22.5 \\
\hline 9.0 & 6.0 & 400 & 5.9 & 5.6 & 14.3 & 14.3 & 8.8 & & $20 \mathrm{~s}$ & 2.8 & 6.7 & & & 10.0 & 5.8 \\
\hline 20.0 & 12.0 & 200 & 23.5 & 11.1 & 14.3 & & 441 & & $\overline{30 s}$ & 33.3 & 16.7 & & 33.3 & 325 & 28.3 \\
\hline 10.3 & 120 & & & |II & & 7.1 & 716 & & $40 \mathrm{~s}$ & 306 & 20.0 & & & 20.0 & 20.8 \\
\hline 16.6 & 180 & 40.0 & 176 & 33.3 & 14.3 & 14.3 & 2.9 & & $50 \mathrm{~s}$ & 5.6 & 6.7 & & & 10.0 & 6.7 \\
\hline 40.0 & 52.0 & & 529 & 33.3 & $57.1 \%$ & 571 & 14.7 & & over 60 & 250 & 200 & 10000 & & 5.0 & 15.8 \\
\hline 76.6 & 863 & 80.0 & 882 & 72.2 & 857 & 929 & 48.5 & 3 & on foot & 743 & 40.0 & 1000 & 750 & 27.5 & 50.4 \\
\hline 2.1 & 2.0 & & & & & 7.1 & 3.0 & way of journey & by bycicle & 5.7 & 267 & & 16.7 & 375 & 22.7 \\
\hline 17.9 & 11.8 & 20.0 & 11.8 & 16.7 & 14.3 & & 3924 & & by car & 20.0 & 33. & & 8.3 & 350 & 26.9 \\
\hline 3.4 & & & & 11.1 & & & 9.1 & & by bus & & & & & & \\
\hline 76.4 & 824 & 80.0 & 64.7 & 833 & 71.4 & 1000 & 60.6 & 4.time of & $10^{1}$ & 857 & 867 & $100 \%$ & 72.7 & 62.5 & 77.1 \\
\hline 19.4 & 15.7 & 20.0 & 35.3 & 11.1 & 28.6 & & 27.3 & journey & $30^{\prime}$ & 14.3 & 13.3 & & 27.3 & 325 & 21.2 \\
\hline 4.2 & 2.0 & & & 5.6 & & & 12.1 & & lh & & & & & 5.0 & 1.7 \\
\hline 32.2 & 480 & 400 & 29.4 & 412 & 14.3 & 42.9 & 3.0 & 5.frequency & every day & 47.2 & 3.3 & 500 & 16.7 & 5.0 & 19.2 \\
\hline 44.8 & 36.0 & 40.0 & 58.8 & 29.4 & 85.7 & 57 & 45.5 & & several a week & 38.9 & 600 & & 583 & 40.0 & 45.8 \\
\hline 13.3 & 12.0 & 200 & 11.8 & 11.8 & & & 242 & & several a month & 5.6 & 33.3 & 5000 & 250 & 20.0 & 20.0 \\
\hline 1.4 & 2.0 & & & & & & 3.0 & & several a year & 2.8 & 3.3 & & & 10.0 & 5.0 \\
\hline 2.1 & & & & & & & 9.1 & & almost never & 5.6 & & & & 17.5 & 7.5 \\
\hline 6.3 & 2.0 & & & 17.6 & & & 15.2 & & others & & & & & 7.5 & 2.5 \\
\hline 57.3 & 68.0 & 40.0 & 388. & 66.7 & 66.7 & 643 & 33.3 & 6.number & alone & 76.5 & 8000 & 50.0 & 36.4 & 15.8 & 53.0 \\
\hline 19.6 & 18.0 & & 294 & 11.1 & 16.7 & 214 & 24.2 & of people & two people & 20.6 & 13.3 & & 36.4 & 395 & 26.1 \\
\hline 23.1 & 14.0 & 60.0 & 11.8 & 22.2 & 16.7 & 14.3 & 924 & & more than tree & 2.9 & 6.7 & $50 \%$ & 27.3 & 447 & 20.9 \\
\hline 3.6 & 3.9 & & & 5.9 & & & 6.9 & 7.time spent & around $10^{\prime}$ & 30.6 & & & & 2.5 & 10.1 \\
\hline 24.5 & 275 & & 500 & 294 & 14.3 & 14.3 & 13.8 & & around $30^{\prime}$ & 300 & & $50 \%$ & 417 & 20.0 & 26.9 \\
\hline 53.2 & 569 & 600 & 37.5 & 47.1 & 857 & 643 & 44.8 & & around $1 \mathrm{~h}$ & 13.9 & 10.3 & 500 & 8.3 & 45.0 & 23.5 \\
\hline 14.4 & 9.8 & 200 & 6.3 & 976 & & 7.1 & 310 & & around $2 \mathrm{~h}$ & 2.8 & 20.7 & . & 500 & 17.5 & 16.8 \\
\hline \multirow[t]{2}{*}{4.3} & 2.0 & 20.0 & 6.3 & & & 14.3 & 3.4 & & around $3 \mathrm{~h}$ & & 13.8 & & & 5.0 & 5.0 \\
\hline & & & & & & & & & more than $3 h$ & 2.8 & 552 & & & 10.0 & 17.6 \\
\hline the whole & pat 1 & pat 2 & pat 3 & pat 4 & pat 5 & pat 6 & pat 7 & \multicolumn{2}{|c|}{ reason to use the park * } & pat 1 & pat 2 & pat 3 & pat 6 & pat 7 & the whole \\
\hline 14.3 & 157 & 2000 & 5.6 & 333 & & 7.1 & 11.8 & \multicolumn{2}{|c|}{ 1. beautiful landsacpe } & 16.7 & & & & 5.0 & 6.7 \\
\hline 45.6 & 41.2 & 40.0 & 667 & 5010 & 714.4 & 571.1 & 29.4 & \multicolumn{2}{|c|}{ 2. richness of green } & 250 & 3.3 & & 8.3 & 2.5 & 10.0 \\
\hline 12.9 & 13.7 & & 11.1 & 33. & 28.6 & 7.1 & 2.9 & \multicolumn{2}{|c|}{ 3. water surface } & & & & & & \\
\hline 20.4 & 11.8 & & 333 & 389 & 571 & 500 & & \multicolumn{2}{|c|}{ 4. fauna andflora } & & & 50.0 & 8.3. & 2.5 & 2.5 \\
\hline & & & & & & & & \multicolumn{2}{|c|}{ 5. to play at the water front } & & & & & & \\
\hline 2.0 & & & & & 28.6 & & 2.9 & \multicolumn{2}{|c|}{ 6. possible to catch insects } & & & & & 2.5 & 0.8 \\
\hline 11.6 & 3.9 & 20.0 & 11.1 & 5.6 & 714 & 28.6 & 5.9 & \multicolumn{2}{|c|}{ 7. people are using } & 5.6 & & & 8.3 & & 2.5 \\
\hline 19.0 & 13.7 & 200 & 11.1 & 5.6 & 28.6 & 7.1 & 412 & \multicolumn{2}{|c|}{ 8. children can play } & 16.7 & 10.0 & & 250 & 400 & 23.3 \\
\hline 20.4 & 9.8 & 1000 & 5.6 & 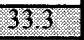 & 14.3 & 21.4 & 26.5 & \multicolumn{2}{|c|}{ 9. to exercise } & 27.8 & 800 & & 583 & 300 & 44.2 \\
\hline 34.0 & 373 & 400 & 38.9 & 27.8 & 87.11 & 57.1 & 14.7 & \multicolumn{2}{|c|}{ 10. for health } & 25.0 & 33.3 & 50.0 & 8.3 & 2.5 & 18.3 \\
\hline 2.7 & 2.0 & 20.0 & & & & 14.3 & & \multicolumn{2}{|l|}{ 11. to refresh } & 2.8 & 6.7 & & 8.3 & 2.5 & 4.2 \\
\hline 17.0 & 13.7 & 200 & 16.7 & 222 & 429 & 286 & 8.8 & \multicolumn{2}{|c|}{ 12. to feel calm } & 13.9 & 6.7 & & 8.3 & 7.5 & 9.2 \\
\hline 54.4 & 47.1 & $80 \%$ & 50.0 & 50.0 & 857 & 929 & 44.1 & 13. close to & home & 583 & 40.0 & 1000 & 66.7 & 47.5 & 51.7 \\
\hline 25.2 & 11.8 & 800 & 50.0 & 22.2 & 571 & 286 & 17.6 & 14. wide & & 58.3 & 50.0 & 50.0 & 50.0 & 625 & 56.7 \\
\hline 8.8 & 7.8 & 400 & 5.6 & 167 & & 7.1 & 5.9 & 15. equipped & d park & 2.8 & 10.0 & 500 & 8.3 & 150 & 10.0 \\
\hline 184 & 13.7 & & 16.7 & 278 & & 7.1 & 324 & 16. others & & 5.6 & 10.0 & & 8.3 & 15.0 & 10.0 \\
\hline
\end{tabular}

\section{Acknowledgements}

Special thanks for Hirohisa Ninoyu for field support.

\section{Notes}

*1) The play field in Ueda-chuo Park is also a regulating pond used for flood control.

*2) A preliminarily research was made to check position and number of investigators necessary in each park The big flat play field and good visibility from the center of Hosoguti-ike Park were reasons to select one investigator for the observation survey.

*3) School or community clubs that were playing baseball, softball and ground golf as organized matches were consider [playing sports] in the observation survey. Informal groups, that were playing soccer, catch ball or dodge ball, were consider [playing with friends]

*4) The highest number of activities in Hosoguti-ike Park is 222(172 are active recreational) at 14:00 p.m. on Sunday, and 216 (174 are active recreational) at 16:00 p.m. on Monday in Ueda-chuo Park. In case of big groups, number of participants was asked to a representative person, before starting the event or the match. And to plot all users in the map (play field) was possible because the players were divided in groups. Usually 20 to 25 players were forming one group.

\section{References}

1) 浦山益郎、秋田道康、城本章広 : 居住環境資源としてみた溜池の利用効果と存在効果 に関する研究，日本建築学会計画系論文集，No.486,pp 129 137, 1996.8

2) 藤井秀人、南勲 : 水管理実態と溜池水量に対する満足度, 農業土木学会論文集, No.126, pp $17 \sim 24,1986$

3) 内田和子:ため池の新しい維持・管理方式に関する考察, 地学雑誌, No.108,pp 263〜275, 1999 .

4) 林直樹、高橋強: 地元住民によるため池高度利用の評牺と整備方向一提言, 農村計画論 文集, pp 139 144, 1999.11

5) 今井敏行、村上康蔵 : 歴史的ため池の保全と活用, 農業土木学会誌第 65 巻, pp 27〜32, 1997.9 .

6）浅田増美、一八瀬友博 : 兵庫県淡路島のため池分布特性とその管理に関寸る研究 農 村計画論文集，第3 集 $\mathrm{pp}$ 79〜84,2001.12.

7）中山徹 : 市民的享受を高めるための緑地空間としての溜め池の保全・活用に関する研 究, 日本都市計画学会学術研究論文集, No.22 pp 7-12, 1987.

8) 客野尚志、鳴海邦碩 : ため池の周辺環境特性とそれらがもたらす水環境機能に関する 研究, 日本建築学会計画系論文集, No.519, pp 195 202, 1999.5

9) 森一彦、西脇智子: 池のある公園におけるベンチの使われ方に関する研究，日本建築学 会計画系論文集, No.585,pp 71 77, 2004.11 


\section{和文概要}

\section{1. 研究の背景・目的}

ため池は灌激用に築造された農業用施設である。都市化に伴い、 多くのため池潅燍用水としての利水機能を失いつつある。しかし、 利水機能だけでなく治水機能、オープンスペース機能、余睱のため の空間提供機能、動植物生息機能など多面的な機能をもっており、 都市環境の質的向上に資寸る可能性をもっている。

ため池に関する研究としては、灌渾施設としての水管理に関する もの、老朽ため池の整㣁に関するもの、ため池の分布や都市化によ るため池の改廃に関するものが多い2～6)。ため池を都市の環境資 源としてみた研究は、中山 ${ }^{7)} 、$ 浦山ら ${ }^{1)} 、$ 客野ら ${ }^{8)}$ など少ない。ま た、ため池の水辺における使われ方を分析したものは森ら ${ }^{97}$ 程度 であり、都市環境資源としてため池を活用するための設計指針は少 ない。

そこで、本研究ではため池を活用した公園整備のための知見を得 ることを目的に、ため池のある公園とない、公園の利用実態を調查し、 特にため池の水辺で行われる余㗇活動の特徽について明らかにし ようとしたものである。

\section{2. 研究の方法}

名古屋市内のため池のある細口池公園とため池のない植田中央 公園 (図 1) を対象に、2004 年 10 月の平日と休日に観察調查とイ ンタビュー方式のアンケート調查を行った（表 $1 \cdot 2$ ）。細口池公園 は地区公園、植田中央公園は近隣公園に指定されているが、住宅地 と中学校が隣接しており、遊歩道、プレイグラウンド、プレイフィ 一ルドなど同様の施設をもっていること、両ため池とも近隣からの 利用者が多いことなと類似性が高い。相違点としては、公園の規模、 ため池の有無である。

\section{3. 両公園における余暇活動}

\section{1）余暇活動の種類}

両公園の利用実態を把握するため、散歩、動的活動 (ジョギング・ スポーツ・友達と遊ぶ・子供と遊ぶ・虫取り）、静的活動（休䄸、 食事・ピクニック・読書・おしやべり・デート・昼寝・緑を眺める・ 花を眺める・池を眺める・鳥を眺める・動物を眺める・虫を眺める） の 3 種類に分けて、午前 6 時から午後 5 時 40 分の間、 20 分ごと に活動位置を地図上にプロットした。細口池公園では休日に延べ 4463、平日に延べ 1607、植田中央公園では休日に延べ 3040、平 日に延べ 1768 の活動が観察できた。両公園ともに休日の利用が多 い。また、ため池のある細口池公園では散歩が多いことがわかった。 2）余暇活動の種類別に見た空間特性

図6のようにゾーンごとに余蚌活動を集計した結果、プレイフィ 一ルドとプレイグラウンドでは、両公園とも動的行為が集中してい た。両公園の違いは、遊歩道を含む堤防エリアにみられた。細口池 公園の堤防 (水辺空間) では散歩や静的活動、動的活動が多様に行 われていた。また、散歩の活動数は植田中央公園周辺の堤防エリア に比べると約 3 倍もあり、ため池の水辺には利用者が多いこと、利 用時間が長いことを示している。

\section{4. 余暇活動の類型化とその特徵}

1）両公園における活動

公園の利用内容を把握するために、表 2 の選択肢を用意して、イ ンタビュー方式によって複数選択の回答を求めた。両公園の相違点
は、細口池公園に散歩および景観を享受する行為である緑を眺める、 花を眺める、池を眺める、鳥を眺める等の静的活動が多いことであ る。一方、植田中央公園では、広いプレイフィールドがあることか らスポーツと子供と遊ぶといら利用内容が多かった。

2）活動の類型化

利用内容 21 項目をクラスター分析した結果、表 3 のように $7 つ$ に類型化できた。類型1 (散歩) と類型2（スポーツ）は単一目的 の活動類型である。類型 3 は、散歩+花を眺める、類型 4 散歩+緑+ 池を眺める、類型 5 は散歩+緑+花+池+鳥を眺める、類型 6 は散歩 +おしやべりのように、複数の活動を行っている類型である。類型 7 はその他である。類型 3〜 5（散歩しながら周囲を酐眺める行為） は、ため池のある細口池公園に特化した余睱活動であることが注目 される。

\section{3）類型別に見た活動の特徵}

活動頑型別に利用者属性をみた (表 4)。類型 1 と類型 3〜 6 は、 50 才代 $\cdot 60$ 才代の中高年齢層が毎日あるいは週に数回、一人で行 う日課的な余昵活動であり、細口池公園に多い類型である。一方、 類型 2 と 7 は若い層が多く、週に数回あるいは月に数回訪れるよう な余㗇活動であり、植田中央公園に多、活動類型であった。

4）類型別に見た公園を利用する理由

細口池公園に多い類型 1 およひ類型 $3 〜 6$ には、周辺に緑が多 いから」や「鳥や花があるから」を選択するものが多く、散歩でき る機能と同時にため池の景観機能を求めてやって来る類型という ことができる。

\section{5. 結論}

1）公園内に設けられた施設（プレイフィールドとプレイグラウ ンド）は動的目的の活動に利用されている。

2）ため池周辺の水辺空間は散歩によく使われている。同時に静 的活動にも動的活動にも多様に利用されている。

3）公園の使われ方を活動の組み合わせによって類型化すると単 一目的 2 つ、多目的の利用 5 つの合計 7 つ類型化できた。

4）類型 $1 、$ 類型 $2 、$ 類型 6 と類型 7 は両公園でみられたが、散 歩しながら周辺を眺める活動である類型 3〜 5はため池のあ る細口池公園に特化した利用であった。

5）類型3〜 5の利用理由は、「周辺に緑が多いから、「花や鳥が あるから」と「水面があるから」などため池のもつ特性を享 受しょうとしたものである。

6）以上のことから、ため池を活かした公園整㣁をするというこ とは、これらため池のもつ便益を享受できるような利用を可 能にすることということができる。

（2005年 2 月 10 日原稿受理， 2005 年 9 月 6 日採用決定 